\title{
Pemanfaatan Ekstrak Kubis Ungu (Brassica Oleraceae) Sebagai Indikator Warna Pada Analisis Hidrokuinon
}

\author{
Susanti, Reny E.E. ${ }^{1}$; Nurjanah, Ana ${ }^{2}$; Safitri, Rika E. ; ${ }^{3}$ 'yun, Qurrata ${ }^{4}$ \\ ${ }^{1,3,4}$ Prodi Kimia, FMIPA, Universitas PGRI Banyuwangi, Banyuwangi \\ ${ }^{2}$ Jurusan Kimia, FMIPA, Universitas Brawijaya, Malang
}

\begin{abstract}
Purple cabbage has distinctive color which is purple due to anthocyanin. Anthocyanin is natural pigmen that has high sensitivity in color change every level of $\mathrm{pH}$ changes acid to base. The anthocyanin sensitivity can be used color indicator. The purpose of this research is utilization purple cabbage extract as color indicator hydroquinone analysis. The research method in this research is maceration extract by executing optimizations such as temperatur optimization and optimization of maceration time. Based on the results of the research has obtained regression equation $\mathrm{y}=0,001 \mathrm{x}+0,0574$ with a value or $\mathrm{R}=0,947$. It can be concluded that purple cabbage extract can be used as color indacator on hydroquinone analysis
\end{abstract}

Kata kunci: Purple Cabbage (Brassica Oleraceae), Color indicator, Hydroquinone.

\begin{abstract}
Abstrak
Kubis ungu mempunyai warna khas yaitu warna ungu yang disebabkan oleh zat antosianin. Antosianin merupakan pigmen alami yang mempunyai sensitifitas tinggi dalam perubahan warna disetiap tigkat perubahan $\mathrm{pH}$ dari asam ke basa. Kepekaan antosianin tersebut dapat dijadikan indikator warna. Penelitian ini bertujan untuk memanfaatkan ekstrak kubis ungu sebagai indikator warna pada analisis hidrokuinon. Metode yang digunakan dalam penelitian ini adalah ekstraksi maserasi, dengan melakukan beberapa optimasi diantaranya optimasi optimasi suhu dan optimasi waktu maserasi. Berdasarkan hasil penelitian diperoleh persamaan regresi $\mathrm{y}=0,001 \mathrm{x}+0,0574$ dengan nilai $\mathrm{R}=0,947$, dapat disimpulkan bahwa ekstrak kubis ungu dapat dijadikan sebagai indikator warna pada analisis hidrokuinon.
\end{abstract}

Keyword: Ekstrak kubis ungu, Indikator warna, Hidrokuinon. 


\section{Pendahuluan}

Hidrokuinon atau pdihidroksibenzena termasuk golongan obat keras yang banyak digunakan untuk sintesis antioksidan dan antiozonan dalam industri karet, industri fotografi, penstabil cat dan industri kosmetik (Badan POM RI, 2011). Pada Kosmetik hidrokuinon sering digunakan sebagai zat pemutih kulit, dan memiliki banyak efek yang tidak menguntungkan dalam pemakaian jangka panjang serta dosis tinggi diantaranya iritasi dermatitis, penghancuran melanosit, dan ochronosis (Siddique, Saima. et al, 2012). Untuk mendeteksi adanya hidrokuinon dapat dilakukan dengan berbagai cara salah satunya dengan menggunakan ekstrak kubis ungu.

Kubis ungu merupakan tanaman herbal dengan daun berwarna ungu biasanya dikonsumsi sebagai salad dan minuman (Maha A et al. 2012). Dalam kubis ungu terdapat banyak komponen bioaktif yaitu isotiosianat, vitamin A,B,C dan antosianin (Jagdish Singh AK et al. 2006). Antosianin merupakan pigmen alami pada kubis ungu yang larut dalam air dan bersifat antioksidan. Selain itu antosisanin dalam kubis ungu mempunyai sensitifitas tinggi dalam perubahan warna disetiap tingkat perubahan $\mathrm{pH}$ dari asam ke basa (Yusuf, Muhammad. 2018).

Kepekaan warna pada antosianin dapat digunakan sebagai komparator dasar, maka diharapkan pada penelitian ini ion antosianin tersebut dapat secara sensitif mendeteksi hidrokuinon. Untuk meningkatkan sensitifitas dalam deteksi perlu dilakukan optimasi dari segi ekstraksi kubis ungu serta pembuatan komparator warna analisis hidrokuinon. Tujuan dari penelitian ini adalah untuk mengetahui apakah ekstrak kubis ungu dapat dijadikan sebagai indikator warna pada analisis hidrokuinon.

\section{Metode Penelitian}

\section{Bahan}

Bahan yang digunakan dalam penelitian ini adalah kubis ungu yang diperoleh dari pasar tradisional, aquades, $\mathrm{NaOH}, \mathrm{HCl}$, buffer fosfat 0,1 $\mathrm{M}, \mathrm{CH}_{3} \mathrm{COONa}$, hidrokuinon.

Alat

Alat yang digunakan dalam penelitian ini adalah pisau, blender, 
alumunium foill, kertas saring, beaker glass, batang pengaduk, neraca analitik, corong gelas, $\mathrm{pH}$ meter, pipet tetes, pipet ukur, labu ukur, gelas ukur, tabung reaksi, pelat tetes, termometer, erlenmeyer dan stopwatch.

\section{Preparasi Sampel}

Kubis ungu yang diiris tipis-tipis ditimbang dan diekstraksi dengan metode maserasi. Maserasi yang digunakan dengan menambahkan 20 $\mathrm{mL}$ air demineralisasi dalam $2 \mathrm{~g}$ kubis ungu dan dimaserasi selama 60 menit. Setelah dimaserasi kemuadian kubis ungu diambil dan dihaluskan dan disaring. Diambil filtratnya.

\section{Uji Fitokimia}

Ekstrak kubis ungu ditambahkan $\mathrm{HCl} 2 \mathrm{M}$ kemudian dipanaskan pada suhu $100^{\circ} \mathrm{C}$ selama 5 menit. Karakteristik antosianin yaitu warna merah tidak akan pudar. Ekstrak kubis ungu ditambah dengan $\mathrm{NaOH} 2 \mathrm{M}$ tetes demi tetes hingga hasilnya terjadi perubahan warna merah menjadi biru dan memudar secara perlahan.

\section{Optimasi Suhu pada Proses}

\section{Ekstraksi Kubis Ungu}

2 gram kubis ungu diiris tipistipis, kemudian ditambahkan $20 \mathrm{~mL}$ air demineralisasi dengan variasi suhu $20^{\circ} \mathrm{C} ; 40^{\circ} \mathrm{C} ; 60^{\circ} \mathrm{C} ; 80^{\circ} \mathrm{C}$; dan $100^{\circ} \mathrm{C}$. Proses maserasi kubis ungu dilakukan selama 60 menit, kemudian kubis ungu hasil maserasi dihaluskan selanjutnya disaring dan diambil filtratnya. Filtrat yang diperoleh diambil sebanyak $1 \mathrm{~mL}$ dimasukkan kedalam tabung reaksi dan ditambah dengan buffer $4 \mathrm{~mL}$ $\mathrm{CH}_{3} \mathrm{COONa} \mathrm{pH} 4,5$ dan tabung yang lain ditambah dengan buffer $\mathrm{CH}_{3} \mathrm{COONa}$ pH 1 dan didiamkan selama 15 menit. Selanjutnya kadar antosianin diuji dengan menggunakan spektro Uv-Vis pada panjang gelombng $510 \mathrm{~nm}$ dan $700 \mathrm{~nm}$.

\section{Pengaruh Waktu Pada Proses Ekstraksi Kubis Ungu}

Hasil optimum variasi suhu pada proses ekstraksi kubis ungu dilanjutkan dengan pengukuran variasi waktu lama maserasi yaitu 5 menit, 15 menit, 30 menit, 45 menit, dan 60 menit. Kubis ungu yang direndam kemudian dihaluskan, kemudian diperas dan disaring dengan menggunakan kertas saring dan diambil filtratnya. Filtrat yang diperoleh diambil sebanyak $1 \mathrm{~mL}$ dimasukkan kedalam tabung reaksi dan ditambah dengan buffer $4 \mathrm{~mL}$ $\mathrm{CH}_{3} \mathrm{COONa} \mathrm{pH} 4,5$ dan tabung yang 
lain ditambah dengan buffer $\mathrm{CH}_{3} \mathrm{COONa}$ pH 1 dan didiamkan selama 15 menit. Selanjutnya kadar antosianin diuji dengan menggunakan spektro Uv-Vis pada panjang gelombng $510 \mathrm{~nm}$ dan $700 \mathrm{~nm}$.

\section{Aplikasi Analisis Hidrokuinon} dengan Ekstrak Kubis Ungu

Uji coba perubahan warna (Komparator) dilakukan dengan menimbang 2 gram kubis ungu yang sudah diiris tipis-tipis dimaserasi dengan menambah $20 \mathrm{~mL}$ aquades $60^{\circ} \mathrm{C}$ selama 45 menit selanjutnya dihaluskan dan disaring. Filtrasi hasil penyaringan diberikan 4 perlakuan yang berbeda (I) $1000 \mu \mathrm{l}$ Buffer pH12 + $300 \mu \mathrm{l}$ ekstrak kubis ungu $+300 \mu 1$ pelarut metanol air (II) $1000 \mu \mathrm{l}$ Buffer pH12 + $300 \mu \mathrm{l}$ ekstrak kubis ungu $+300 \mu \mathrm{l}$ hidrokuinon; (III) $1000 \mu$ l Buffer pH12 $+300 \mu 1$ aquades $+300 \mu 1$ hidrokuinon; dan (IV) $1000 \mu \mathrm{l}$ aquades $+300 \mu \mathrm{l}$ ekstrak kubis ungu $+300 \mu \mathrm{l}$ hidrokuinon

Pengaruh $\mathrm{pH}$ buffer fosfat pada proses ektraksi kubis ungu yaitu dengan mereaksikan $1000 \mu$ l Buffer + $300 \mu \mathrm{l}$ ekstrak kubis ungu $+50 \mu \mathrm{l}$ hidrokuinon $500 \mathrm{ppm}$. Bufer fosfat 0,1
$\mathrm{M}$ dengan $\mathrm{pH} 3,4,5,6,7,8,9,10,11$, dan 12.

Uji Kalibrasi (pembuatan kurva standar yaitu $1 \mathrm{~mL}$ ekstrak ditambah $2 \mathrm{~mL}$ buffer fosfat dicampurkan hidrokuinon dengan variasi konsentrasi 100 - 1000 ppm, ditambah 4 mL aquades kemudian diukur dengan spektro UV-Vis dengan panjang gelombang $628 \mathrm{~nm}$.

\section{Hasil dan Pembahasan}

Proses ekstraksi kubis ungu menggunakan metode maserasi, yaitu dengan merendam kubis ungu yang diris tipis-tipis dengan aquades selama 60 menit. Setelah dimaserasi kemudian kubis ungu dihaluskan dan diperas selanjutnya disaring dengan menggunakan kertas saring. Diperoleh filtrat kubis ungu berwarna ungu sesuai dengan warna dari kubis ungu itu sendiri. (gambar 1). 


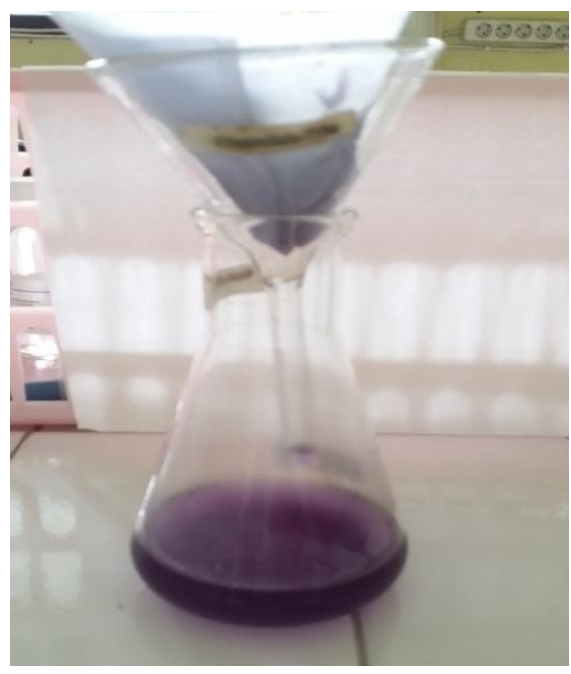

Gambar 1. Filtrat Kubis Ungu

Uji fotokimia untuk mengidentifikasi adanya senyawa antosianin (gambar 2) yang terkandung dalam kubis ungu. Uji fitokimia dilakukan dengan menambahkan ekstak kubis ungu dengan HCL 2M kemudian dipanaskan menghasilkan warna merah dan tidak memudar. Dilanjutkan dengan penambahan $\mathrm{NaOH} \quad 2 \mathrm{M}$ ternyata menghasilkan warna hijau dan secara perlahan menjadi kuning (Gambar 3). Hal tersebut membuktikan bahwa dalam kubis ungu terdapat zat antosianin, jika dalam keadaan asam akan berwarna merah dan jika dalam keadaan basa akan berwarna biru ke hijau sampai kuning. Hal ini sesuai dengan Marco et all (2011) menyatakan bahwa pada $\mathrm{pH} \quad 1-2$ antosianin dominan dalam bentuk kation flavilium yang berwarna merah, pada $\mathrm{pH}<6$ berubah menjadi karbinol dan sebagian menjadi kuinonoidal yang berwarna biru sehingga berwarna ungu, pada $\mathrm{pH}$ 6,5 - 9 dominan kuinonoidal yang berwarna biru, pada $\mathrm{pH}>9$ kalkon yang berwarna hijau kuning.

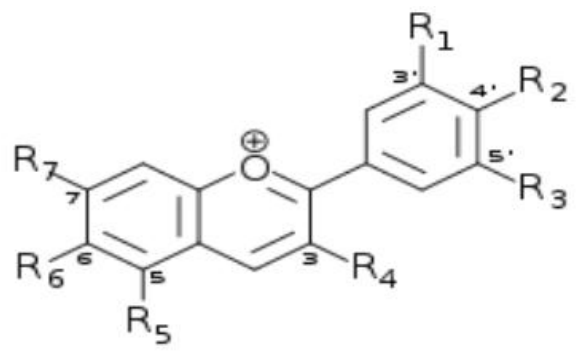

Gambar 2. Struktur Antosianin 
Susanti, dkk. Akta Kimia Indonesia 4(2), 2019, 95-106

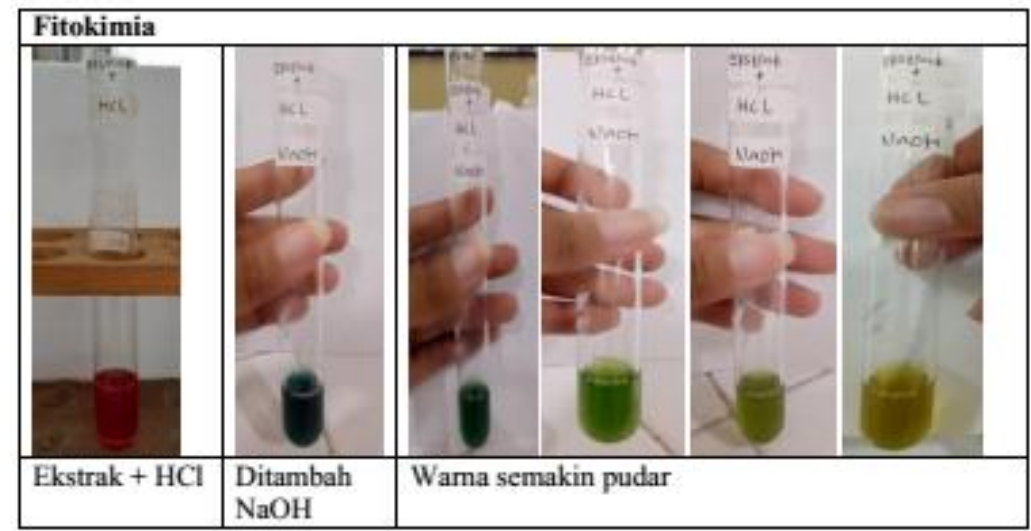

Gambar 3. Uji Fitokimia

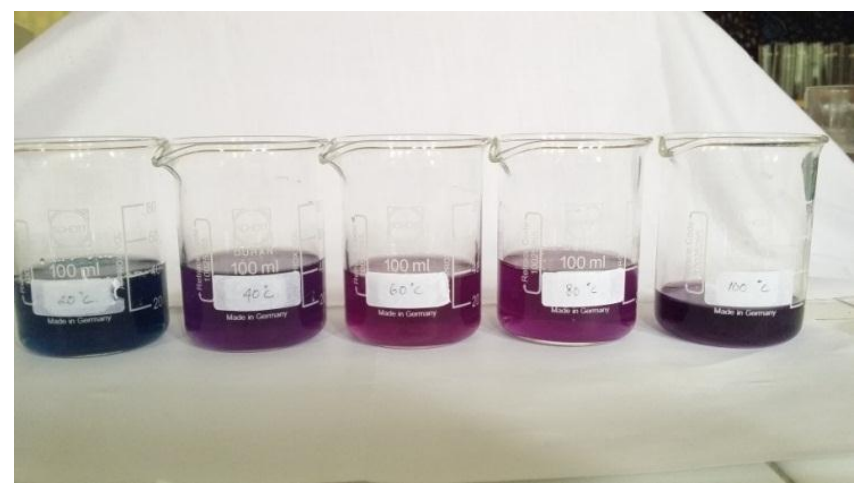

Gambar 4. Ekstrak Kubis Ungu Variasi Suhu Air Rendaman

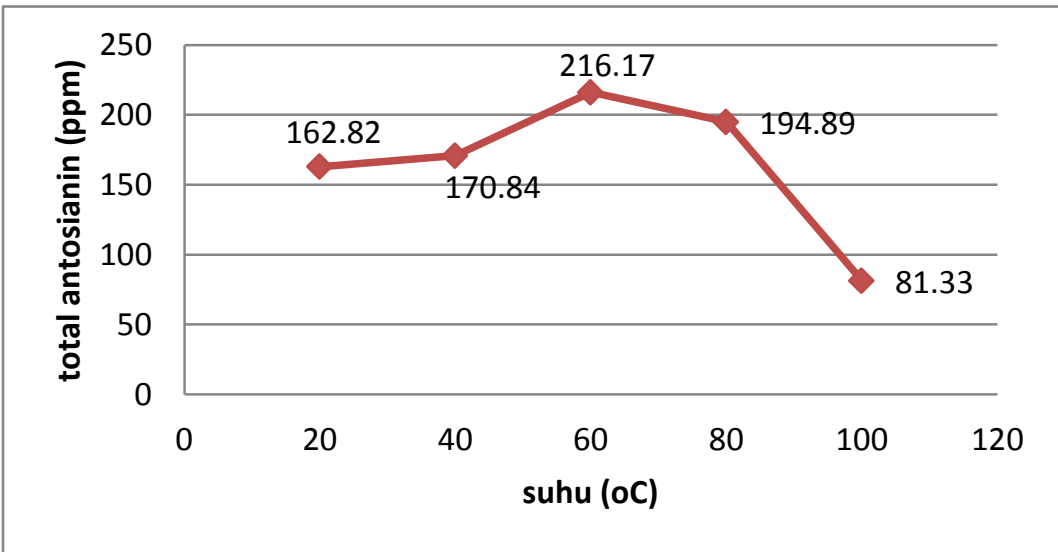

Gambar 5. Grafik Pengaruh Suhu Air Rendaman pada Ekstraksi Kubis Ungu Terhadap Kadar Antosianin

Kestabilan antosianin

dipengaruhi juga oleh $\mathrm{pH}$ sehingga dalam suasana asam kuat akan tetap berwarna merah meskipun dipanaskan 
sekalipun dan dalam suasana basa kuat akan tetap berwarna kuning (Gustriani, $d k k, 2016)$.

Pengaruh suhu air rendaman pada proses maserasi diamati pada suhu 20 , $40,60,80$ dan $100^{\circ} \mathrm{C}$, hasil pengamatan dapat dilihat pada gambar 4. Kadar Antosianin diukur dengan menggunakan spektro Uv-Vis dengan panjang gelombang 510 dan $700 \mathrm{~nm}$ yang sebelumnya ekstrak kubis ungu ditambahkan buffer $\mathrm{CH}_{3} \mathrm{COONa} \mathrm{pH}$ 4,5 dan $\mathrm{pH}$ 1. Berdasarkan hasil perhitungan menunjukkan bahwa kadar antosianin pada suhu $60^{\circ} \mathrm{C}$ lebih banyak yaitu 216,17 ppm, dan kadar antosianin akan semakin berkurang seiring dengan tingginya suhu (Gambar 5). Suhu ekstraksi yang terlalu tinggi akan menyebabkan warna pigmen alam semakin memucat disebabkan lepasnya gugus glikosil pada antosianin karena hidrolisis glikosidik (J. B. Adam, 1973).

Pengaruh waktu pada proses maserasi kubis ungu diamati yaitu dengan cara maserasi kubis ungu yang sudah diiris tipis-tipis dengan suhu air rendaman $60^{\circ} \mathrm{C}$ dengan waktu rendaman yang berbeda beda. Waktu rendaman yang dilakukan dan diamati adalah 5, 15, 30, 45 da 60 menit. Kadar Antosianin diukur dengan menggunakan spektro Uv-Vis dengan panjang gelombang 510 dan $700 \mathrm{~nm}$ yang sebelumnya ekstrak kubis ungu ditambahkan buffer $\mathrm{CH}_{3} \mathrm{COONa} \mathrm{pH}$ 4,5 dan $\mathrm{pH}$ 1. Hasil pengamatan dapat dilihat pada gambar 6 dan gambar 7 . Berdasarkan garafik tersebut dapat kita amati bahwa kadar antosianin paling tinggi terdapat saat waktu maserasi selama 45 menit yaitu 207,66 ppm. Semakin lama waktu maserasi total antosianin yang diperoleh semakin menurun, hal ini kemungkinan disebabkan pada saat 45 menit merupakan titik jenuh maserasi dan memicu turunnya aktifitas ekstrasi dari pelarut. 
Susanti, dkk. Akta Kimia Indonesia 4(2), 2019, 95-106

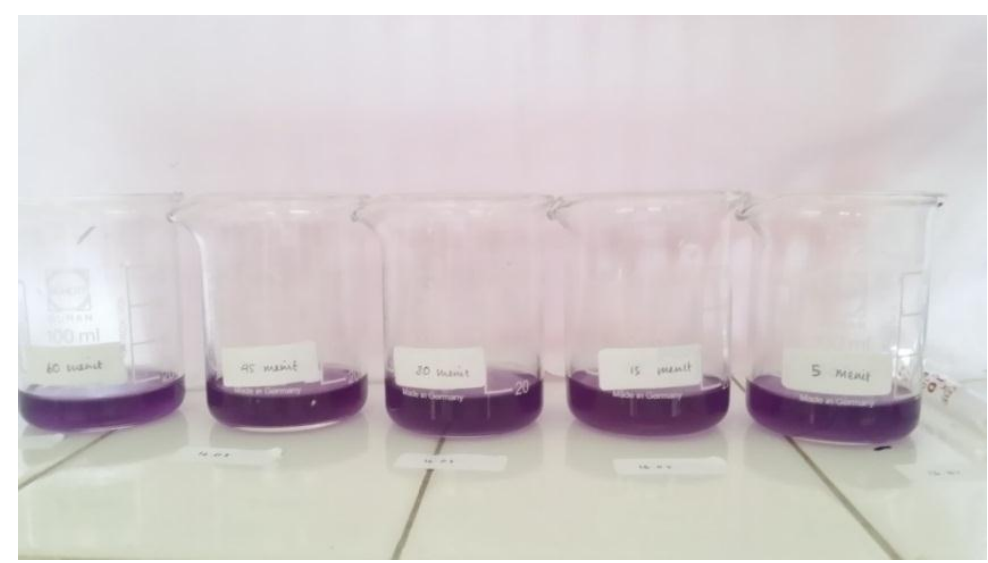

Gambar 6. Ekstrak Kubis Ungu Variasi Waktu Maserasi

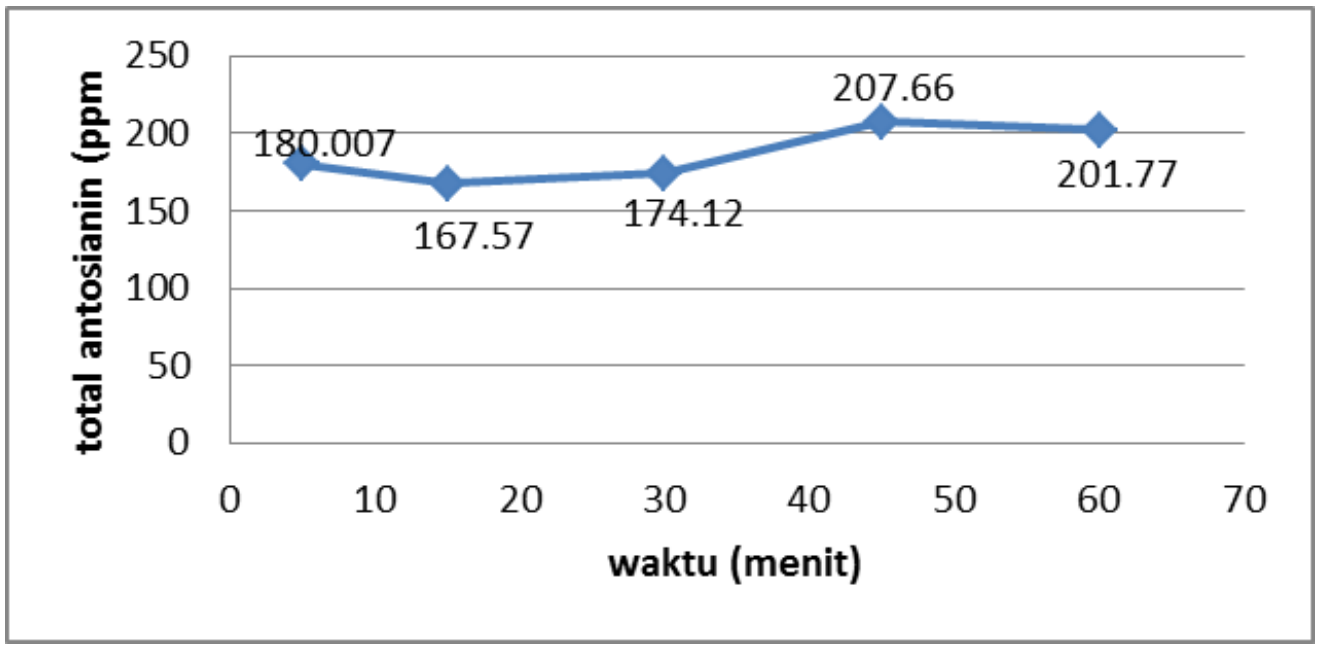

Gambar 7. Grafik Pengaruh Waktu Maserasi pada Ekstraksi Kubis Ungu Terhadap Kadar Antosianin

Gambar 8 Uji Selektifitas Komparator Warna/ uji reagen (I) Buffer pH12 + Ekstrak + Metanol air; (II) Buffer pH12 + Ekstrak + Hidrokuinon; (III) Buffer pH12 Aquades + Hidrokuinon; (IV) Aquades + ekstrak + Hidrokuinon 
Dalam aplikasi analisis hidrokuinon ekstrak kubis ungu menggunakan pelarut aquades, dikarenakan dengan menggunakan pelarut aquades dapat teramati komparasi warnanya. Uji coba perubahan warna meliputi empat perlakuan yang berbeda, dari keempat perlakuan tersebut yang menghasilkan perubahan warna yang signifikan adalah perlakuan kedua yaitu dari biru muda menjadi hijau kecoklatan. Berdasarkan hal tersebut maka pemberian perlakuan sesuai dengan urutan bufer fosfat $\mathrm{pH} 12$, ekstrak kubis ungu selanjutnya hidrokuinon (gambar 8). Hal ini disebabkan hidrokuinon merupakan senyawa elektroaktif yang dapat mengalami reaksi oksidasi yang dipengaruhi oleh pelarut. Hidrokuinon akan bermuatan aktif pada kondisi 912, dan jika ekstrak ditambahkan buffer fosfat maka ekstrak juga akan bermuatan aktif sehingga memungkinkan untuk bereaksi aktif dengan hidrokuinon (Petrangolini, 2011). Buffer fosfat dipilih karena larutan tersebut dapat digunakan untuk mendeteksi kestabilan senyawa hidrokuinon (Safitri, 2014).

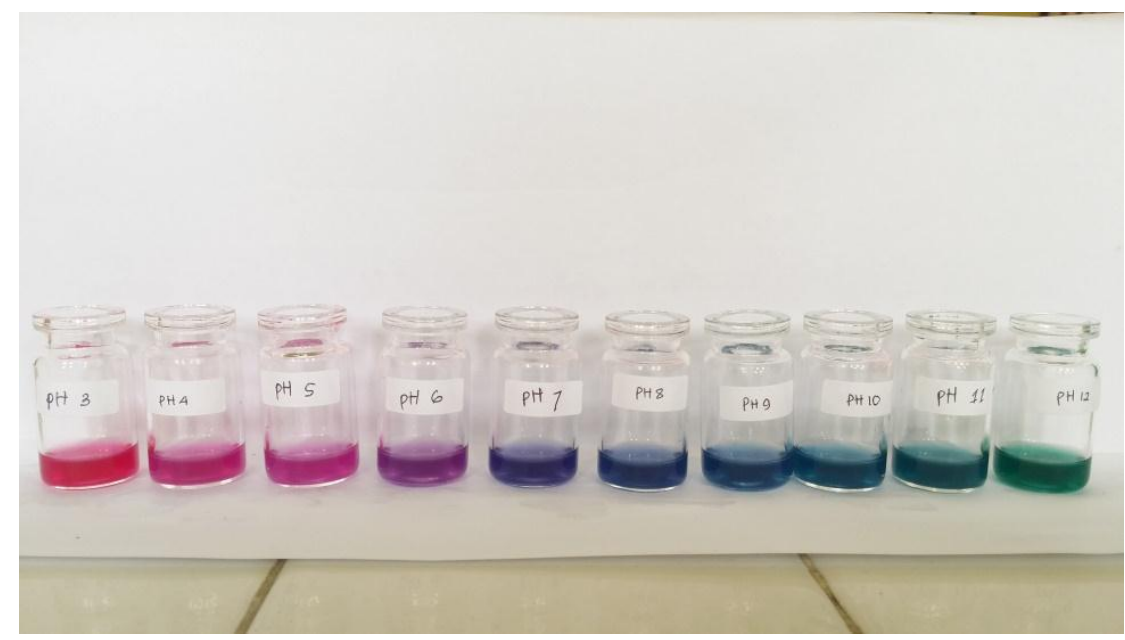

Gambar 9 Pengaruh pH Terhadap Perubahan Warna Ekstrak Kubis Ungu

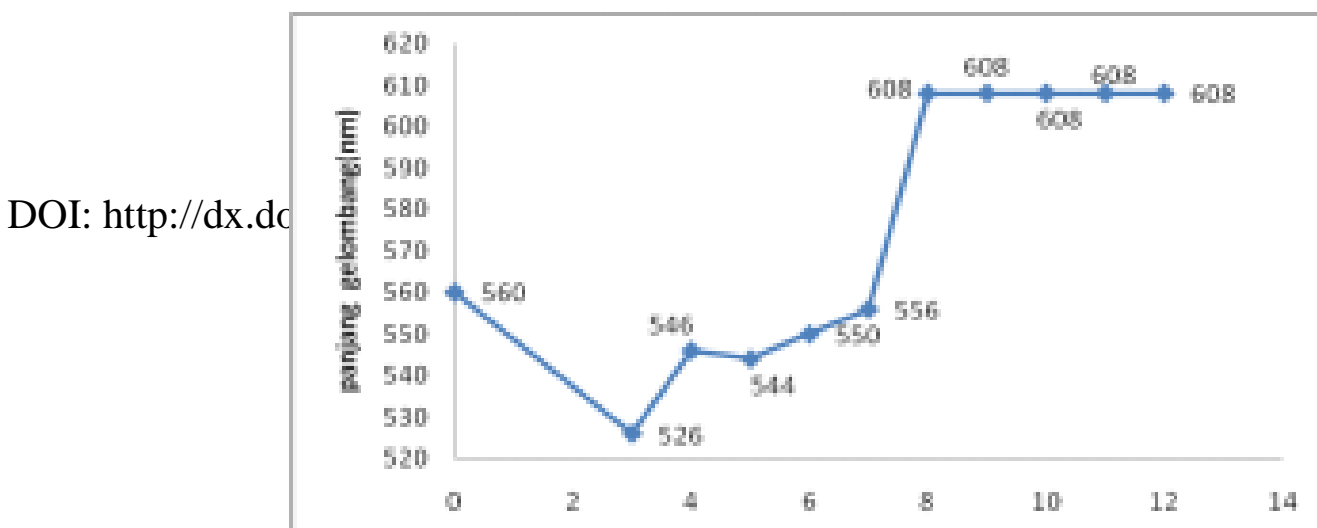


Susanti, dkk. Akta Kimia Indonesia 4(2), 2019, 95-106

Gambar 10 Grafik Hubungan Pengaruh pH dengan Absorbansi

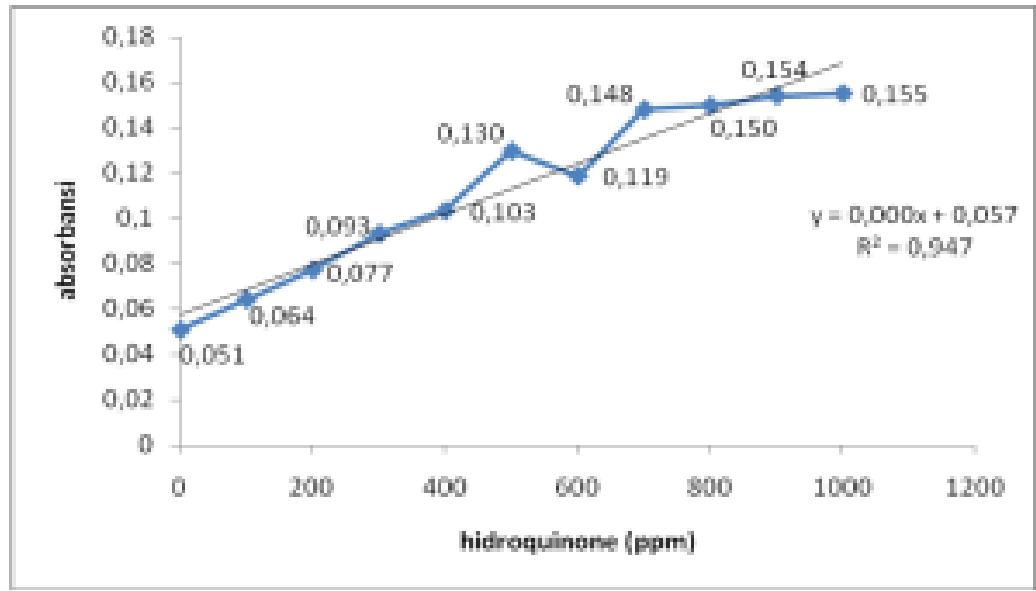

Gambar 11 Grafik Kurva Standart

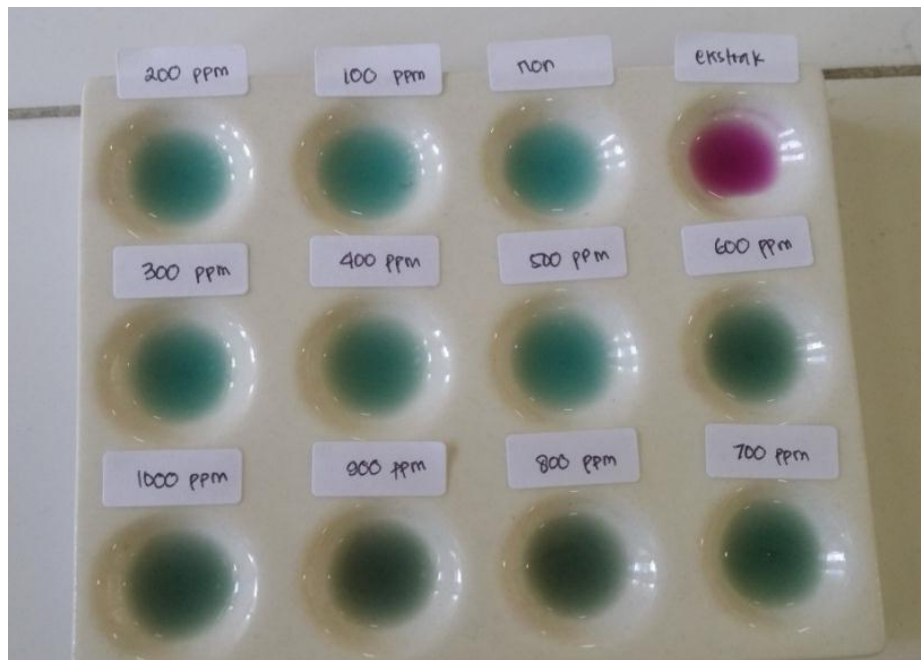

DOI: http://dx.doi.org/10.12962/j25493736.v4i2.5134 


\section{Gambar 12 Uji Komparator Warna Adanya Hidrokuinon dengan Ekstrak Kubis Ungu}

Pengaruh variasi $\mathrm{pH}$ pada penentuan kadar antosianin dalam kubis ungu dengan metode UV-Vis pada kisaran $\mathrm{pH}$ 3-12 dalam larutan buffer fosfat dan hasilnya dapat dilihat pada gambar 9 dan gambar 10. Pada gambar 10 dapat dilihat bahwa semakin tinggi $\mathrm{pH}$ buffer fosfat maka nilai absorbansi tinggi, selain itu warna pigmen antosianin terlihat sangat jelas berwarna hijau (gambar 9). Hal ini sesuai dengan warna antosianin pada kubis ungu mengalami perubahan warna ungu-biru pada kisaran $\mathrm{pH}$ 6,57,5 warna hijau-hijau kebiruan pada kisaran $\mathrm{pH}$ 10,5-12 dan warna hijau kebiruan-kuning pada kisaran $\mathrm{pH}$ 12,00-13,00 (Gusriani, N, dkk. 2016).

Pada tahap $\begin{array}{r}\text { pengukuran } \\ \text { mengkalibrasi }\end{array}$
standarisasi atau
hidrokuinon dengan menggunakan
larutan hidrokuinon pada 100-1000
ppm dan diukur dengan menggunakan
spektrofotometri UV-Vis dengan
panjang gelombang 628 nm. Hasil
kurva standart dapat dilihat pada
gambar 10 dan untuk perubahan warna
(komparator warna) yang dihasilkan
dapat dilihat pada gambar 11.

Berdasarkan kurva standar tersebut diperoleh persamaan regresi $\mathrm{y}=$ $0,001 x+0,0574$ dengan nilai $\mathrm{R}=$ 0,947. Slope atau nilai kemiringan pada kurva standar tersebut dapat digunakan untuk melihat sensitifitas suatu metode analisis (Gandjar, Ibnu Galih, dkk. 2008) dan nilai korelasinya adalah baik karena mendekati 1 yaitu 0,947 . Berdasarkan perubahan warna dapat dilihat pada gambar 12 tampak bahwa semakin banyak kandungan hidrokuinon maka larutan akan berwarna hijau kecoklatan.

\section{Kesimpulan}

Dari hasil penelitian ini dapat disimpulkan bahwa ekstrak kubis ungu dapat digunakan sebagai indikator warna pada analisis hidrokuinon. Sampel yang positif mengandung hidrokuinon dengan range 700-1000 ppm akan memberikan degradasi warna hijau kecoklatan.

\section{Daftar Pustaka}

[1] Badan POM RI. 2011. Hidrokuinon, http://ik.pom.go.id/v2016/katalog/Hidrok uinon_upload.pdf, [8 September 2018] 
[2] Yusuf, M., Indriati, Sr., Attahmud, Nur, F. Karakteristik Antosianin Kubis Merah Sebagai Indikator Pada Kemasan Cerdas, Jurnal Galung Tropika, 7(1), 4655.

[3] Gandjar, Ibnu Galih, dkk. 2008. Kimia Farmasi Analisis. Yogyakarta: Pustaka Pelajar.

[4] Gustriani, N., Novitriani, K., Mardiana, U. Penentuan Trayek pH Ekstrak Kubis Ungu (Brassica Oleracea L) Sebagai Indikator Asam Basa Dengan Variasi Konsentrasi Pelarut Etanol, Jurnal Kesehatan Bakti Tunas Husada, 16 (1), 94-100. [5] D. Ebehard and E. Voges, "Digital single sideband detection for interferometric sensors," presented at the 2nd Int.Conf. Optical Fiber Sensors, Stuttgart, Germany, 1984.

[5] Jagdish Singh AK, Upadhyay A, Bahadhur B, Singh B, Singh KP, Mathura Rai AK. Antioxidant phytochemical in cabbage (Brassica Oleracea L. var. capitata). Scientia Horticulture 2006; 108:233-237

[6] J. B. Adams. 1973. Thermal Degradation of Anthocyanins with
Particular Reference to The 3-Glycosides of Cyanidin I. In Acidified Aqueous Solution at 100 deg. J.Sci. Food Agri 24: 747-762.

[7] Maha A. El-Motaleb el-Mowafy. Treatment Effect of Red Cabbage and Cysteine against Paracetamol Induced Hepatotoxicity in Experimental Rats, Journal of Applied Sciences Reseach. 2012; 8(12):5852-5859.

[8] Marco PH, Poppi RJ, Scarminio IS, Tauler R. 2011. Investigation of the $\mathrm{pH}$ effect and UV radiation on kinetic degradation of anthocyanin mixtures extracted from Hibiscus acetosella. Food Chem 125: 1020-1027. DOI: 10.1016/j.foodchem.2010.10.005.

[9] Petrangolini, P., Quinone/Hydroquinone Redox Reaction Studied by EC-STM: Implication for Molecular Electronics, Disertasi, Fisica e Nanoscienze

[10] Safitri, Alfita. 2014. Penentuan Hydroquinone secara Voltametri menggunakan Elektroda Karbon ScreenPrinted 